\title{
O DIREITO FRATERNO COMO PARADIGMA NA EFETIVIDADE DO DIREITO À SAÚDE INDÍGENA
}

\section{THE FRATERNAL RIGHT AS PARADIGM IN EFFECTIVENESS OF RIGHT TO HEALTH INDIGENOUS}

\author{
${ }^{1}$ Florisbal de Souza Del'Olmo \\ ${ }^{2}$ Ana Paula Cacenote
}

\section{Resumo}

Diante da ineficiência do Estado referente à efetivação dos direitos humanos dos povos indígenas, torna-se necessária a adoção de novos padrões socioculturais, em especial, no direito à saúde. Através de pesquisas bibliográficas e da aplicação dos métodos fenomenológico e comparativo, tem-se como norte o Direito Fraterno, enquanto substancializador dos meios e processos permanentes de reconhecimento do Outro. Decorre na construção de uma base cultural despida de uma identidade legitimadora, mas sustentável em uma natureza dialógica, onde a liberdade e a igualdade, enquanto práticas sociais, repercutem sobre as possibilidades da autonomia individual/coletiva e da efetividade do direito à saúde indígena.

Palavras-chave: Direito Fraterno; Saúde Indígena; Inefetividade; Direitos Humanos; Paradigma.

\begin{abstract}
Given the inefficiency the State regarding the realization of human rights of indigenous peoples, it is necessary to adopt new social and cultural patterns, in particular, the right to health. Through bibliographical searches and the application of phenomenological methods and comparative, it has north Fraternal Right, while substantiate of means and permanent processes of recognition the Other. It follows the construction of a naked cultural base of legitimating identity, but sustainable in dialogic nature, where freedom and equality, as social practices have an impact on the possibilities of individual or collective autonomy and the effectiveness the right to indigenous health.
\end{abstract}

Keywords: Fraternal Law; Indigenous Health; Ineffectiveness; Humans Law; Paradigm.

\footnotetext{
${ }^{1}$ Mestre pela Universidade Federal de Santa Catarina, UFSC - SC, (Brasil). Doutor em Direito Universidade Federal do Rio Grande do Sul, UFRGS - RS, (Brasil). Pós-Doutor em Direito pela Universidade Federal de Santa Catarina, UFSC - SC, (Brasil). E-mail: florisbaldelolmo@ gmail.com.

${ }^{2}$ Mestre em Direitos Especiais pela Universidade Regional Integrada do Alto do Uruguai e das Missões Campus Santo Ângelo (URI). E-mail: anapaulacacenote@hotmail.com
} 


\section{CONSIDERAÇÕES INICIAIS}

A proteção à saúde, assegurada na Constituição Federal da República Brasileira de 1988 é consagrada como sendo um dos direitos mais importantes do rol dos Direitos Humanos, uma vez que proporciona aos cidadãos, uma melhor qualidade de vida, contribuindo assim para o desenvolvimento físico, intelectual e espiritual. E como o referido direito é de caráter universal e igualitário, ele atende também os grupos sociais vulneráveis, as minorias da população brasileira.

A contemporaneidade é marcada pela complexidade das relações sociais, advindas da globalização, dos avanços tecnológicos, da diversidade cultural, da economia, entre outros fatores responsáveis. Contudo, tais mudanças contribuíram para o enfraquecimento do sistema estatal, e consequentemente para a violação dos direitos fundamentais, em especial o direito à saúde indígena.

Com o intuito de reverter essa problemática, o ensaio propõe, através pesquisas bibliográficas e da aplicação dos métodos fenomenológico e comparativo, a construção de um novo modelo sociocultural na efetividade do direito à saúde indígena a partir da igualdade e da liberdade estabelecidas pelo Direito Fraterno. A cultura proposta tem como diretrizes para a resolução dessa violação o diálogo, o reconhecimento das diferenças, a autonomia, o amor e a liberdade, a igualdade e a participação ativa dos profissionais da saúde com a medicina convencional e os indígenas com seus conhecimentos da medicina tradicional.

Diante da mortalidade que assola a população indígena, ocasionada por doenças infecciosas e pela falta de assistência médica, o Direito Fraterno apresenta-se adequado para a realização do direito à saúde indígena e para a preservação da cultura e do conhecimento medicinal tradicional desses povos, uma vez que busca, por meio da cooperação entre povos, entre as culturas, a concretização dos direitos humanos.

\section{ASPECTOS HISTÓRICOS DOS POVOS INDÍGENAS}

A sociedade indígena contemporânea é marcada por uma multiplicidade de violações de direitos humanos fundamentais, dentre eles, o direito à saúde. Desta forma, a presente pesquisa tem como escopo investigar as causas da não efetividade do direito à saúde dos povos 
indígenas, bem como apresentar a necessidade e os benefícios em construir um novo paradigma cultural no atendimento à saúde indígena por meio do Direito Fraterno.

Para uma melhor compreensão acerca da temática proposta, torna-se necessário resgatar, de forma breve, a história das injustiças sofridas pela população indígena no Brasil.

O processo de colonização das Américas é marcado por um inacreditável aniquilamento dos povos indígenas, onde muitos perderam suas vidas, e os que restaram tiveram sua cultura represada pelos colonizadores. Neste contexto, assevera Tzvetan Todorov (1999, p. 158):

Se a palavra genocídio foi alguma vez aplicada com precisão a um caso, então é esse. É um recorde, parece-me, não somente em termos relativos (uma destruição da ordem de $90 \%$ e mais), mas também absolutos, já que estamos falando de uma diminuição da população estimada em 70 milhões de seres humanos. Nenhum dos grandes massacres do século XX pode comparar-se a esta hecatombe.

Cumpre ressaltar que a invasão deturpadora dos colonizadores nas Américas se deu por espanhóis, ingleses, franceses e portugueses, que, mediante a utilização da violência e da exploração, dominaram os povoados indígenas, para impor suas intenções ambicionistas, de cunho mercantil, religioso e cultural (BAGGIO, 2009).

No viés do reconhecimento e do respeito ao outro, esse enfrentamento é fruto da rejeição da alteridade, o que denota a essencialidade do reconhecimento e da dignidade humana, independente de suas diferenças. Contudo, a aparente/dissimulada bondade dos europeus perante os índios, escondia suas reais intenções, que, além de mercantilista e exploratória, buscava também a supressão identitária dos povos ameríndios, ou seja, negavam o valor da diferença.

Tal aniquilamento cultural e identitário dos povos indígenas é resultado de muito sofrimento, submissão e até mesmo de extermínio de seus corpos. Nas palavras de Baggio (2009, p. 38), os colonizadores visualizavam os ameríndios da seguinte forma:

Os indígenas, pois, não passam, nesta visão, de criaturas domesticáveis, de grande habilidade manual passível de ser posta a serviço dos elevados intentos cristãos dos colonizadores do imaginário do povo conquistado, mas absolutamente incapazes do exercício da razão; verdadeiramente, não se constituem em seres aptos à cognição, ao raciocínio mais elevado, quem sabe aproximando-se, no máximo, do nível de discernimento e compreensão das coisas alcançado por uma criança europeia. E se, assim, se lhes retira boa parte da racionalidade, se extirpa precisamente uma grande parcela da característica mais essencial da condição humana - dotada de dignidade fundada justamente nas bases da pressuposta autonomia dada pela racionalidade de todo o homem [...]. E aí compreende-se, também, o fundamento da negação das diferenças e 
a tentativa assimilacionista, fundada nesse imenso preconceito e má-compreensão das capacidades, interesses e, enfim, do próprio universo dos indígenas.

Além disso, no século XVI, grande parte dos povos ameríndios teve suas vidas ceifadas em razão dos surtos de doenças infecciosas, advindas com a colonização, ou seja, dos maus tratos, da escravização do trabalho indígena, da perda da autoestima e dos valores comunitários.

A diminuição da população nativa pelos espanhóis ocorreu por três motivos, quais sejam: por assassinato, durante as guerras; por maus tratos; e por choque bacteriano (TORODOV, 1999). Os maus tratos ${ }^{3}$ se caracterizaram pelas péssimas condições de trabalho. Já as doenças infectocontagiosas foram disseminadas pelos espanhóis, de maneira consciente nos indígenas. Consoante ao exposto, o autor supracitado (1999, p. 159) evidencia que:

[...] Os conquistadores consideram as epidemias como uma de suas armas; não conhecem os segredos da guerra bacteriológica, mas, se soubessem, não deixariam de utilizar conscientemente as doenças; pode-se também imaginar que, na maior parte das vezes, eles nada fizeram para impedir a propagação das epidemias.

Vale salientar que no período da colonização os missionários aliados às políticas do governo, acompanharam os grupos indígenas. Em meados de 1910, com o opulento número de índios mortos por chacina e doenças, foi criado o Serviço de Proteção ao Índio e Trabalhadores Nacionais (SPI), que ligado ao Ministério da Agricultura, tinha como escopo proteger e auxiliar os índios no manejo de suas terras.

Antes de adentrar na análise do sistema estatal de efetivação do direito à saúde, tornase imprescindível observar o direito à saúde indígena na perspectiva da Teoria Sistêmica.

\section{O DIREITO À SAÚDE NA PERSPECTIVA DA TEORIA SISTÊMICA}

\footnotetext{
${ }^{3}$ Dentro do contexto dos maus tratos, Tzvetan Todorov afirma: "Paralelamente ao aumento da mortalidade, as novas condições de vida também provocam uma diminuição da natalidade: "Eles não mais se aproximam das esposas, para não engendrar escravos”, escreve o mesmo Zumarraga ao rei; e Las Casas explica: “Assim, marido e mulher não ficavam juntos e nem se viam durante oito ou dez meses, ou um ano; e quando, ao cabo desse tempo, se encontravam, estavam tão cansados e abatidos pela fome, tão prostrados e enfraquecidos, tanto uns quanto as outras, que pouco se preocupavam em manter comunicações maritais. Deste modo, pararam de procriar. Os recémnascidos morriam cedo, pois suas mães, cansadas e famintas, não tinham leite para nutri-los. Por isso, enquanto eu estava em Cuba, 7.000 crianças morreram em três meses. Algumas mães chegavam a afogar os filhos por desespero, enquanto outras, vendo-se grávidas, provocavam abortos com certas ervas, que produzem crianças natimortas".
} 
O surgimento de recursos tecnológicos, como também o aparecimento de novas doenças, contribuíram para a intensificação da complexidade sanitária. Entretanto, a saúde deve ser interpretada como um recurso sistêmico que estabelece relações com os outros sistemas sociais, produzindo uma incerteza oculta.

Assim, a razão de a saúde ser um sistema aberto e operacionalmente fechado, faz com que a troca mútua de ingerências e de comunicação do sistema saúde com os demais acarrete na contingência/relativização das possibilidades do referido sistema, resultando assim, na criação de sistemas e subsistemas, cada qual com suas características e peculiaridades próprias (SCHWARTZ, 2001). Portanto, o direito à saúde indígena é um subsistema do direito, pois dispõe de uma estrutura e especificações intrínsecas ao atendimento sanitário dos índios.

Como o direito à saúde é um sistema que age de forma preventiva, de modo a evitar situações indesejáveis, a matriz sistêmica do direito torna-se adequada, pois busca atenuar as incertezas e os descasos referentes à saúde. E um dos instrumentos que o direito utiliza para reduzir a complexidade é a norma jurídica, denominada por Leonel Severo Rocha, como “programação condicional para decisões". Todavia, pode o sistema jurídico se utilizar de outros instrumentos, que não a norma, para atender as demandas do sistema. Neste caso, a complexidade não será reduzida, recaindo na indeterminação.

Atinente ao contexto, Rocha (2013, p. 336) afirma que:

[...] a sociedade moderna possui condições de controlar as indeterminações, ao mesmo tempo que não cessa de produzi-las. Isto gera um "paradoxo" na comunicação. Nesta ordem de raciocínio, para Luhmann, a pesquisa jurídica deve ser dirigida para uma nova concepção da sociedade centrada na complexidade, baseada em postulados tais capazes de possibilitar a observação não apenas dos paradoxos existentes na sociedade, mas também da compreensão complexa da noção de risco, que numa perspectiva sistêmica nos sugere relevantes significações.

Logo, pode-se afirmar que o sistema saúde pode ser inefetivo. O sistema jurídico interage com o sistema sanitário quando este tem seu ato violado ou inefetivado, oportunidade em que acontecerá a comunicação entre o sistema da saúde e o sistema jurídico, para decidir sobre o assunto (SCHWARTZ, 2001).

Ainda que de forma breve, a pequena explanação sobre a teoria sistêmica, demonstra que o direito à saúde indígena é um subsistema do direito, em que ambos possuem estruturas e características próprias, e interagem entre si e com os demais subsistemas por meio da comunicação. 
Depois de apresentado o direito à saúde indígena como um subsistema do direito, fazse necessário analisar como o Estado está atuando na redução da complexidade e da violação do referido direito.

\title{
3 A ATUAÇÃO DO ESTADO NA EFETIVAÇÃO DO DIREITO À SAÚDE DOS POVOS INDÍGENAS
}

O direito à saúde foi consagrado pela Constituição Federal de 1988 como uma norma fundamental, pois sua efetivação deve acontecer de forma universal e igualitária, incluindo a população indígena no rol de sujeitos amparados pela Carta Magna, com as pertinentes particularidades com relação ao princípio da igualdade, de maneira a proporcionar bem-estar e uma vida digna às pessoas, sem qualquer forma discriminatória e desigualitária. Nesse aspecto, Marieta Izabel Martins Maia (2010, p. 45) enfatiza:

\begin{abstract}
A Constituição brasileira quando afirma que é objetivo fundamental da República Federativa construir uma sociedade livre, justa e solidária, pode-se constatar, claramente, o reconhecimento de dimensões ou categorias constitucionais materializadas em três valores distintos, porém se encontram em simbiose perfeita, para integrar definitivamente o Direito numa atuação mais concreta e eficaz com a sociedade. São elas uma dimensão política: construir uma sociedade livre; outra, social: construir uma sociedade justa, com igualdade e por último, uma dimensão humanística/ interpessoal: construir uma sociedade fraterna/solidária.
\end{abstract}

Tais dimensões são imprescindíveis para a efetivação dos direitos humanos da população, em especial o direito à saúde. Conforme Ingo Sarlet (apud SANTOS In STURZA; GRANADO; LUCION, 2014), o direito à saúde possui uma dupla fundamentalidade, quais sejam: material que é a preservação ao bem jurídico tutelado - a vida digna e com qualidade, mediante preceito constitucional; e também é um direito diretamente aplicável, cabendo às instituições estatais aplicar de forma imediata.

A Carta Magna aborda com especificidade a saúde, a partir do artigo 196 até o 200. O artigo 196 assegura que a saúde é um direito de todos e dever do Estado, devendo ser garantida por meio de ações afirmativas, sociais, econômicas, que proporcionem a minimização das 
doenças. No entanto, cabe ao Estado, ${ }^{4}$ através de políticas públicas primar pela saúde da população brasileira (SANTOS In STURZA; GRANADO; LUCION, 2014).

O artigo 198 retrata sobre o sistema único de saúde, o qual deve atender de forma individual e coletiva a população indígena, sempre observando o princípio da unicidade, da integralidade, da humanização e do mínimo existencial (SANTOS In STURZA; GRANADO; LUCION, 2014).

Todavia, os povos indígenas foram ter acesso ao sistema único de saúde somente em meados de 1999, momento em que foi criado o Subsistema de Atenção à Saúde Indígena. A demora na criação do referido órgão justifica-se nos obstáculos no decorrer da história, como a marginalização, a desigualdade e a exclusão dos ameríndios (SANTOS In STURZA; GRANADO; LUCION, 2014).

O Subsistema de Atenção à Saúde Indígena possui um atendimento diferenciado, até mesmo na assistência médica, compatível com a cultura e com o costume indígena. Apesar desse atendimento alternativo existir, ele ainda se demonstra deficiente na viabilização dos objetivos propostos, principalmente na utilização da medicina convencional com a medicina tradicional (LANGDON; DIEHL apud SANTOS In STURZA; GRANADO; LUCION, 2014).

No decorrer da história foram criadas normas infraconstitucionais com o intuito de consolidar programas e políticas públicas de proteção à saúde indígena. A primeira legislação foi o Estatuto do Índio, a Lei $n^{\circ} 6.001 / 1973$, a qual prima pela integração dos índios no âmbito nacional. Em 1999 foi criado o Decreto ${ }^{\circ}$ 3.156, que normatiza as condições para prestação de assistência à saúde indígena. O referido decreto regulamentou a Política Nacional de Atenção à Saúde dos Povos Indígenas.

Cumpre ressaltar que houve também o surgimento de entidades de apoio aos povos indígenas, como a Fundação Nacional do Índio e a Fundação Nacional de Saúde, dentre outras, que caminham para a proteção dos direitos indígenas.

\footnotetext{
${ }^{4}$ Para Castells, as relações de poder são constitutivas da sociedade porque aqueles que detêm o poder constroem as instituições segundo seus valores e interesses. O poder é exercido por meio da coerção (o monopólio da violência, legítima ou não, pelo controle do estado) e/ou pela construção de significado na mente das pessoas, mediante mecanismos de manipulação simbólica. As relações de poder estão embutidas nas instituições da sociedade, particularmente nas do Estado. Entretanto, uma vez que as sociedades são contraditórias e conflitivas, onde há poder há também contrapoder - que consideramos a capacidade de os atores sociais desafiarem o poder embutido nas instituições da sociedade com o objetivo de reivindicar a representação de seus próprios valores e interesses. Todos os sistemas institucionais refletem as relações de poder e seus limites tal como negociados por um interminável processo histórico de conflito e barganha. A verdadeira configuração do Estado e de outras instituições que regulam a vida das pessoas depende dessa constante interação entre poder e contrapoder.
} 
A proteção da saúde indígena visa também tutelar os conhecimentos tradicionais medicinais no tratamento de doenças. Tal proteção denota a necessidade da integração entre os índios e o Estado para a efetivação do direito à saúde indígena, e a manutenção dos saberes tradicionais. Para tanto, deve-se trabalhar na conscientização de sua relevância, nas entidades públicas, privadas e sociais (SANTOS In STURZA; GRANADO; LUCION, 2014).

Entretanto, atualmente a população indígena vem passando por uma variedade de violações de seus direitos, como na demarcação de terras, no direito à saúde, à alimentação, à moradia, e principalmente, o direito à vida. Como o objeto deste estudo é o direito à saúde indígena, as estatísticas serão voltadas para esse segmento.

Segundo o Jornal El País, os índices de mortalidade infantil dos indígenas por doenças infecciosas e pela falta de assistência médica, menores de um ano, são alarmantes. Na maioria dos estados brasileiros, o número de mortes triplicou. Para se ter uma ideia, no estado de Amazonas a população indígena, no Médio Rio Solimões e Afluentes, correspondente em 2014, a 17.597 , teve uma taxa de mortalidade de $52,79 \%$ de crianças menores de um ano, sendo que no ano de 2011, o índice era de 7,91\%. Em Roraima, a população conta com 21.249 índios, e a taxa de mortalidade infantil em 2015 foi de 149\%, em contrapartida em 2004, tal índice estava em 69,84\%. No Amapá e Norte do Pará, a população indígena de 10.875, teve taxa de mortalidade de 74,84\%, comparado a 2011, o índice era de $13,12 \%$. No Litoral Sul do País (estados do Rio de Janeiro, São Paulo, Paraná, Santa Catarina e Rio Grande do Sul), a população indígena, de 10.610, teve índice de mortalidade infantil em 2013 de 44,67\%, enquanto em 2007, o número de mortos tinha sido de $15,17 \% .^{5}$

Diante dessa verdadeira catástrofe que assola a população indígena brasileira, tomandose por base a pesquisa bibliográfica, fica evidenciado a inefetividade do Estado no atendimento ao direito à saúde dessa parcela da população brasileira. Apesar de o governo federal ter duplicado a verba no atendimento à saúde, os postos de atendimento aos índios ainda se demonstram precários, com a falta de médicos e a disponibilidade de recursos para o deslocamento dos profissionais da saúde em tribos isoladas, de difícil acesso, o que contribui para essa tragédia.

Além dos aspectos materiais, pode-se afirmar que o descaso com a saúde da população indígena advém da repulsa de parte da população, e porque não dizer, dos operadores do Estado,

\footnotetext{
${ }^{5}$ Jornal El País, disponível em http://brasil.elpais.com/especiais/2015/saude-indigena/. Acesso em 24 set. 2016.
} 
consoante aos grupos indígenas. Em outras palavras, a sociedade ameríndia ainda é vítima de práticas discriminatórias, de desigualdade e de expulsão, em pleno século XXI. O desrespeito, a indiferença e o não reconhecimento soam alto no cenário social contemporâneo.

Atinente à temática de igualdade, diferença e de reconhecimento, bem como dos efeitos da globalização nas culturas, cabem algumas palavras para melhor compreensão da importância do Direito Fraterno na efetivação do direito à saúde indígena.

\section{A EFETIVAÇÃo do DIREITO À SAÚde INDÍGENA À LUZ DO DIREITO FRATERNO}

A evolução da humanidade é marcada por lutas, violência, opressão, entre outros, ocasionadas pelas desigualdades, pelas diferenças sociais e culturais. É bem verdade que a Constituição Federal de 1988 assegura amplo rol de direitos, como os direitos humanos e sociais. Contudo, a vigência de um texto legal não é suficiente: é preciso mecanismos para efetivá-lo. Para tanto, se torna necessário uma mudança consciente das pessoas na forma de requerer a efetivação de seus direitos, no intuito de utilizar o direito fraterno para a realização dos direitos humanos, do acesso à justiça, da dignidade humana, da democracia e do exercício da cidadania, consolidados na Carta Magna.

Ao se referir sobre a relação identidade e diferença, Kathryn Woodward (apud SILVA, 2000, p. 50), ressalta: “A diferença pode ser construída negativamente - por meio da exclusão ou da marginalização daquelas pessoas que são definidas como "outros" ou forasteiros. Por outro lado, ela pode ser celebrada como fonte de diversidade, heterogeneidade e hibridismo, sendo vista como enriquecedora”. Desse modo, os grupos indígenas no contexto atual devem ser respeitados como iguais e diferentes: iguais na essência, e diferentes nas perspectivas externas/alheias à composição dos seres humanos (BAGGIO, 2009).

Cumpre ressaltar que a relação ${ }^{6}$ entre indivíduo e sociedade é baseada na complementaridade e no antagonismo; complementar porque assim como a sociedade depende

\footnotetext{
${ }^{6}$ A relação indivíduo - sociedade é hologramática, recursiva e dialógica: hologramática: o indivíduo está na sociedade que está no indivíduo; recursiva: a relação sociedade-indivíduo não se realiza, em primeiro lugar, por um determinismo social capaz de tolerar margens de liberdade individual, mas conforme um anel de produção mútua indivíduos/sociedade no qual as interações entre indivíduos produzem a sociedade; esta constitui um todo organizador, cujas qualidades emergentes retroagem sobre os indivíduos incorporando-os. A sociedade controla e regula as interações que a produzem e garante sua continuidade através da incorporação das novas gerações de
} 
do ser humano para existir, o ser humano depende da sociedade. Já a relação de antagonismo advém da opressão dos desejos e pulsões do homem por parte da sociedade, uma vez que, tais pulsões violam as normas da sociedade, e estas por consequência, reprimem a espécie humana (MORIN, 2007).

Além disso, o caráter antagônico de tal relação é ambivalente, uma vez que a complementaridade sustenta o antagonismo e o antagonismo sustenta a complementaridade (MORIN. 2007). Deste modo, a sociedade dispõe simultaneamente de interesses individuais e coletivos, de disputas econômicas, conflitos de ordem pessoal e coletiva, de lutas das camadas sociais, entre outras, mas também comporta organizações comunitárias que prezam pela união e solidariedade dos povos.

A seu turno, a dialógica complementaridade e antagonismo, presente nas relações sociais, contribui para a intensificação da complexidade, e consequentemente da desordem social, pois sustenta relações cada vez mais paradoxais, entre integração e desintegração, espírito comunitário e de rivalidade, ocasionando a violação dos direitos fundamentais.

A sociedade atual se encontra em crise frente às mudanças consequentes da globalização, o que antes era a sociedade moderna impulsionada pela unificação e racionalidade social, agora passa a sofrer com a incerteza e a instabilidade das relações humanas. Nesse contexto, Niklas Luhmann afirma que: [...] "encontramo-nos num tempo depois da modernidade, que necessita de uma nova "trama categorial", que deveria mover-se num terreno multi e interdisciplinar" (MORIN, 2007, p. 167-168).

Vale dizer que a globalização, ao mesmo tempo em que unifica a sociedade, também a divide, visto que, para alguns as dimensões globais são compreendidas como globalização, e para outros como localização: para os primeiros, tal processo indica liberdade e para os segundos, uma fatalidade. Assim, a mobilidade percorre o mais elevado nível dos valores desejados, qual seja, a liberdade de movimentos, que se apresenta como um produto deficiente

indivíduos. Assim, os indivíduos produzem a sociedade que produz os indivíduos; a emergência social depende da organização mental dos indivíduos, mas a emergência mental depende da organização social; dialógica: a relação indivíduo/sociedade é, de múltiplas formas, ao mesmo tempo complementar e antagônica. MORIN, Edgar. O método 5: a humanidade da humanidade. Tradução de Juremir Machado da Silva. Porto Alegre: Sulina, 2007, p. 167-168.

Revista de Sociologia, Antropologia e Cultura Jurídica |e-ISSN: 2526-0251|Curitiba|v. 2 |n. 2 |p.1009 - 1026|Jul/Dez. 2016. 
e partilhado de maneira desigual, razão pela qual se torna a causa basilar da disparidade social, parafraseando Zygmunt Bauman (2009).

Desse modo, a polaridade global/local contribui para a complexidade do convívio em sociedade, conforme salienta o aludido autor (2009, p. 08):

Todos nós estamos, a contragosto, por desígnio ou à revelia em movimento. Estamos em movimento mesmo que fisicamente estejamos imóveis: a imobilidade não de uma opção realista num mundo em permanente mudança. E, no entanto, os efeitos dessa nova condição são radicalmente desiguais. Alguns de nós se tornam plena e verdadeiramente "globais", alguns se fixam na sua "localidade" - transe que não é nem agradável nem suportável num mundo em que os "globais" dão o tom e fazem as regras do jogo da vida.

Sob o comando do poder, as elites globais estabelecem condições que afastam os grupos locais das zonas públicas, das atividades econômicas e sociais. Assim, as comunidades e grupos locais, como os indígenas, estão perdendo o espaço para criar e negociar, diante dos obstáculos que impedem sua interação no âmbito social, econômico, cultural e político.

Para compreender melhor a pluralidade cultural da sociedade, como também a violação dos direitos fundamentais dos grupos vulneráveis, torna-se imprescindível o debate sobre o conceito de multiculturalismo. O multiculturalismo constitui uma mescla de diversas realidades culturais que resultam na criação e propagação de bens culturais. Deste modo, o referido instituto busca suprimir o pensamento único, dando espaço para as múltiplas visões acerca de um mesmo assunto, através do diálogo entre as culturas. Contudo, há aqueles que interpretam o multiculturalismo como um fenômeno negativo, por causar a intensificação dos conflitos e, consequentemente, a instabilidade na sociedade. Nesse sentido, Alain Touraine (1997, p. 224225) enfatiza que o multiculturalismo:

[...] não é nem uma fragmentação sem limites do espaço cultural, nem um melting pot cultural mundial: procura combinar a diversidade das experiências culturais com a produção e a difusão de massa dos bens culturais. Não há sociedade multicultural possível sem o recurso a um princípio universalista que permita a comunicação entre indivíduos e grupos social e culturalmente diferentes. Mas também não há sociedade multicultural possível se este princípio universalista determina uma concepção da organização social e da vida pessoal considerada normal e superior às outras.

Cabe mencionar a existência de dois tipos de multiculturalismo, quais sejam: o universal e o relativista. $\mathrm{O}$ primeiro determina o reconhecimento e a coexistência de múltiplas culturas, 
desde que esteja estipulado um denominador comum (também chamado de cultura política compartilhada) para facilitar o diálogo. O segundo configura-se quando há ausência de parâmetros mínimos para a comunicação entre as culturas, uma vez que cada cultura estipula seus valores (MADERS; DUARTE, 2012).

Nesse sentido, Eligio Resta (RESTA, 2004, p. 11) afirma:

[...] O hoje indica uma época que vê desgastar-se a forma estatal das pertenças fechadas, governadas por um mecanismo ambíguo que inclui os cidadãos, excluindo todos os outros. Mas significa também a época em que vão sendo experimentadas outras formas de convivência política. [...] O direito fraterno coloca, pois, em evidência toda a determinação histórica do direito fechado na angústia dos confins estatais e coincide com o espaço de reflexão ligado ao tema dos Direitos Humanos, com uma consciência a mais: a de que a humanidade é simplesmente o lugar "comum", somente em cujo interior pode-se pensar o reconhecimento e a tutela.

Dessa forma o direito fraterno busca a comunhão, a partilha de culturas, ideias, interesses, direitos entre os povos, independentemente das diferenças e da soberania. Portanto, o paradigma fraternidade apresenta-se como uma aposta, que vai para além das barreiras estatais, que utiliza meios de exclusão social e cultural. O propósito está em superar as limitações de cunho territorial, e avançar um lugar comum, conduzido pelo reconhecimento e pelas diferenças.

$\mathrm{O}$ entendimento de fraternidade ${ }^{7}$ está vinculado à solidariedade na perspectiva de consciência ética, jurídica, política e cultural, a qual se mantém neutra/imparcial para com a diversidade de grupos vulneráveis e minoritários. O exercício da solidariedade é que agracia ao ser humano a humanidade.

Com o Direito Fraterno surge a possibilidade de um novo paradigma de regras da comunidade, um modelo jurado conjuntamente entre irmãos, e não imposto. Consoante ao exposto, Resta (2004, p. 15-16) afirma que:

[...] conduz ao sentido de uma aposta: a aposta em jogo é a diferença do direito em relação ao mundo que pretende regrar. Enfim, trata-se de um modelo de direito que abandona a fronteira fechada da cidadania e olha em direção à nova forma de

\footnotetext{
${ }^{7}$ Conforme Marieta Izabel Martins Maia, existem dois tipos de fraternidade/solidariedade que são essenciais à convivência humana, um ligado às formas de convívio e outro relacionado ao bem-estar social geral que visa, sobretudo, a justiça. Faz-se mister explicitar que a primeira diz respeito à padronização de costumes e modos de vida, incluindo-se aqui a homogeneização de questões como o trabalho, a economia, o transporte, a comunicação, o lazer, a cultura, a política, dentre outras; enquanto a segunda, essencialmente, ética, alicerçada no respeito aos direitos humanos, objetiva a construção de uma cidadania mundial, independente das relações de dominação e poder.
} 
cosmopolitismo que não é representada pelos mercados, mas pela necessidade universalista de respeito aos direitos humanos.

Para Sandra Regina Martini Vial, o Direito Fraterno é um direito jurado conjuntamente entre irmãos; é um direito despido das amarras de uma identidade para legitimá-lo; é um direito que reverbera a humanidade como sendo um lugar comum a todos; é um direito não violento; e ainda um direito que busca uma inclusão ilimitada (VIAL, 2007).

Na perspectiva das políticas públicas do Estado, vale destacar o entendimento de Vial (2007, p. 135):

[...] quando se tratam de bens comuns da humanidade, devem-se observar as políticas sociais tendo-se presente a forma como estas atuam em uma sociedade, não mais definida geograficamente, mas em uma sociedade de mundo. Nela, é preciso pesquisar o impacto das políticas sociais; no presente caso, o impacto das políticas que pretendem uma inclusão social e a tutela dos direitos fundamentais, analisando-se de que modo elas são efetivas e eficazes [...] Note-se que muitos destes programas, ditos inclusivos, acabam, muitas vezes, mascarando o mapa da exclusão social ou, ainda, mascarando os problemas de fundo.

No entanto, o Direito Fraterno representa ser um instrumento capaz de conduzir os direitos indígenas, em especial, o direito à saúde, com magnitude e sobriedade. Permite também o reconhecimento e a compreensão da dialética iguais e diferentes dos índios, bem como da constituição de um ambiente público, garantido pelo Estado, direcionado para uma política fraterna, que conscientize a sociedade para o reconhecimento, para a diferença e para a efetivação dos direitos humanos dos povos indígenas.

O caráter democrático do Direito Fraterno baseia-se nas características e na metodologia dessa prática, tendo em vista o seu cunho pacificador e inclusivo no tratamento e prevenção do direito à saúde indígena. É através do diálogo, do respeito, da igualdade, da participação ativa, da solidariedade que se realiza a efetividade do direito à saúde indígena.

O Direito Fraterno também é uma forma ampla de exercício da cidadania, e para explicar esta relação faz-se necessário trazer o conceito de cidadania. O termo cidadania sofreu ao longo do tempo uma redefinição, o que antes era compreendido como exclusão, hoje passa a ter o entendimento de inclusão. Neste sentido, Warat (2010, p. 3-4) assevera:

[...] aprendi que os excluídos têm existência sem cidadania, os esquecidos nem sequer têm o mínimo sentido da própria identidade. Os excluídos têm sentimentos de revolta contra a exclusão [...]. Os esquecidos não têm consciência de que são esquecidos; nem sequer podem verbalizar para si mesmos sua condição de esquecidos [...]. Não adianta 
chegar a eles outorgando-lhes o título de eleitor, e achando que assim se integram à cidadania. A Justiça do Brasil para eles tem que ser pedagógica e terapêutica.

O Direito Fraterno também adota essa visão ampla do exercício da cidadania, pois instiga a humanidade na tomada de suas decisões, ressaltando o potencial, a responsabilidade e a liberdade de escolha de cada um, de maneira que cada um seja o protagonista da transformação de sua própria realidade.

Quanto à realização da dignidade humana ${ }^{8}$ através do direito fraterno, cumpre ressaltar dois aspectos pertinentes ao referido princípio, que são: a dignidade como uma condição inerente à espécie humana, ao passo de ser inalienável e intransmissível, dado o seu meio qualificador. Outro aspecto corresponde ao empenho de cada pessoa em buscar uma vida digna pelo convívio em sociedade. Sendo assim, a dignidade está atrelada à autodeterminação da espécie humana, bem como à necessária proteção do Estado e da sociedade (MOREIRA, 2007).

Compreender, sobretudo, o direito fraterno como criação cultural e como consciência pedagógica, requer a superação do entendimento abstrato e idealista, que visualizava a paz como um ideal distante/utópico. Logo, tal superação exige das pessoas, o estímulo para exercer a sua capacidade de praticar a alteridade ${ }^{9}$ e o respeito às diferenças culturais, uma vez que, a realização da saúde não é de responsabilidade restrita do Estado, cabendo a cada um exercê-la.

$\mathrm{O}$ fio condutor do Direito Fraterno na efetivação do direito à saúde dos povos ameríndios está na busca constante pelo bem-estar da humanidade, mediante a construção de um futuro promissor, voltado para as questões coletivas, inclusivas e solidárias.

É digno destacar a contribuição do Direito Fraterno na concretização da inclusão social, diante da desigualdade social e econômica que assola a população brasileira. A exclusão social ${ }^{10}$

\footnotetext{
${ }^{8}$ Para Ingo Wolfgang Sarlet, a dignidade humana no contexto constitucional brasileiro é definida como uma qualidade intrínseca e distintiva reconhecida em cada ser humano que o faz merecedor do mesmo respeito e consideração por parte do Estado e da comunidade, implicando, neste sentido, um complexo de direitos e deveres fundamentais que assegurem a pessoa tanto contra todo e qualquer ato de cunho degradante e desumano, como venham a lhe garantir as condições existenciais mínimas para uma vida saudável, além de propiciar e promover sua participação ativa e co-responsável nos destinos de sua própria existência e da vida em comunhão com os demais seres humanos.

${ }^{9}$ Para Marieta Izabel Martins Maia a alteridade está vinculada à subjetividade, e isso é fundamental porque significa abrir-se para o outro. E abrir-se para o outro pressupõe aceitar e viver a experiência de que não somos, apenas, uma individualidade, uma identidade fixa, mas um permanente processo de evolução, na condição de afetar e sermos afetados pelo outro, implica numa transcendência, é uma verdadeira ultrapassagem da individualidade, enfim encerrando em si a intersubjetividade e a comunicação em torno de uma esfera comum de ética, princípios e valores.

${ }^{10}$ Conforme André Campos, a exclusão se manifesta sob múltiplos aspectos em várias dimensões da vida nacional. [...] nota-se que, ao longo da segunda metade do século XX, de maneira sempre reiterada, quase metade das 27 unidades federativas brasileiras apresentou índices aflitivos de pobreza, sendo que a mesma quantidade exibiu índices sofríveis de assalariamento formal. Mais de um terço mostrou índices inaceitáveis de desigualdades de
} 
manifesta-se em diversas formas, tendo como forma velha de exclusão aquela que omite a qualidade de cidadania, e a partilha dos recursos econômicos a determinados grupos sociais.

\section{CONSIDERAÇÕES FINAIS}

O Direito Fraterno apresenta-se como um instrumento eficaz na realização da inclusão social, pois busca a valorização da espécie humana e do seu conhecimento acerca de sua função de integração no convívio em sociedade, bem como o incentivo à cidadania e o respeito à dignidade humana.

Dessa forma, o entendimento do Direito Fraterno não está vinculado somente aos valores e à ética, mas também às normas jurídicas, as quais devem ser interpretadas e aplicadas de maneira flexível e interconexa com todos os sistemas e subsistemas da sociedade.

Todavia, a fraternidade necessita de um consenso da humanidade para a sua efetivação, ou seja, a solidariedade somente se manifestará se a sociedade estiver disposta a vivê-la, uma vez que sua prevalência depende não do interesse do poder estatal, mas da necessidade da

rendimentos, enquanto dois terços revelaram índices precários de alfabetização e escolaridade. Finalmente, cerca de metade apresentou índices preocupantes de violência e, como síntese, igual número revelou índices críticos de exclusão. É bem verdade que as unidades da federação que se mostraram sob estas condições em 1960, 1980 e 2000 foram frequentemente as mesmas (quase sempre localizadas nas regiões norte e, principalmente, nordeste [sic]. Mas em hipótese alguma isso tornou a questão menos grave, inclusive porque tais unidades responderam continuadamente por $35 \%$ da população nacional. Ou seja, ao longo de toda a segunda metade do século, mais de um terço dos brasileiros se encontrou vivendo sob velhas e novas formas de exclusão social. 
coletividade em viver com paz. Contudo, a questão não está na ausência de conflitos que envolvam violações de direitos, até porque isso seria impossível, dado o conflito ser inerente à vida humana e em razão da complexidade social. O ponto chave para a realização da fraternidade está na criação de espaços propícios para a reflexão, a negociação, a alteridade, o diálogo, o reconhecimento do outro, e para a pacificação dos conflitos.

Diante da complexidade das relações sociais da contemporaneidade e do enfraquecimento do sistema estatal na efetivação do direito à saúde indígena, a adoção do Direito Fraterno apresenta-se eficaz no alcance à saúde e aos demais direitos fundamentais, uma vez que, através do seu potencial igualitário, solidário e humano, busca a efetivação do direito sanitário aos povos indígenas, através da assistência e da interação da medicina tradicional e convencional, bem como a formação de uma sociedade mais justa e tolerante, que prime pela diminuição das desigualdades, pelo reconhecimento dos direitos humanos, da democracia e do exercício de cidadania.

\section{REFERÊNCIAS}

BAGGIO, Moacir Camargo. Revista Direitos Culturais. V. 1, n. 1, Jul./Dez. 2009.

BAUMAN, Zygmunt. Globalização: as consequências humanas. Tradução Marcus Penchel. Rio de Janeiro: Jorge Zahar Editor, 1999.

CASTELLS, Manuel. Redes de indignação e esperança: movimentos sociais na era da internet. Tradução Carlos Alberto Medeiros. Rio de Janeiro: Zahar, 2013.

JORNAL El País. Disponível em http://brasil.elpais.com/especiais/2015/saude-indigena/. Acesso em 24 set. 2016.

LAKATOS, Eva Maria; MARCONI, Marina de Andrade. Fundamentos de Metodologia

Científica. 7. ed. São Paulo: Editora Atlas, 2010.

LÉVINAS, Emmanuel. Entre Nós: ensaio sobre a alteridade. Petrópolis: Vozes, 1997. 
MADERS, Angelita Maria; DUARTE, Isabel Cristina Brettas. Multiculturalismo e Direito. Santo Ângelo: FuRI, 2012.

MAIA, Marieta Izabel Martins. Direito Fraterno: em busca de um novo paradigma jurídico. https://repositorio-aberto.up.pt/bitstream/10216/63904/2/TESE\%20MARIETA\%20OK.pdf Acesso em 22 set. 2016.

MOREIRA, Sandra Mara Vale. Mediação e Democracia: uma abordagem contemporânea da resolução de conflitos. http://pt.scribd.com/doc/75525424/2/A-EVOLUCAO-DADEMOCRACIA-E-A-NATUREZA-DEMOCRATICA.

MORIN, Edgar. O método 5: a humanidade da humanidade. Tradução Juremir Machado da Silva. Porto Alegre: Sulina, 2007.

RESTA, Eligio. O Direito Fraterno. Tradução Sandra Regina Martini Vial. Santa Cruz do Sul: EDUNISC, 2004.

ROCHA, Leonel Severo. Epistemologia Jurídica e Democracia. São Leopoldo: Unisinos, 1998.

ROCHA, Leonel Severo. Paradoxos da Auto-Observação: percursos da Teoria Jurídica Contemporânea. 2. ed. Ijuí: UNIJUÍ, 2013.

RODRIGUES, Leo Peixoto; NEVES, Fabrício Monteiro. Niklas Luhmann: sociedade como sistema. Porto Alegre: EdiPUCRS, 2012.

SANTOS, Denise Tatiane Girardon dos. Povos Indígenas e Direito à Saúde: os Programas de Saúde Pública voltados aos indígenas no Brasil. In: STURZA, Janaína Machado; GRANADO, Juliana Bedin; LUCION, Maria Cristina Schneider (Orgs.). Estado, Políticas Públicas e Direito à Saúde: Ensaio sob a Égide dos Direitos Humanos. Santa Cruz do Sul: Essere nel Mondo, 2014.

SARLET, Ingo Wolfgang. Dignidade da pessoa humana e direitos fundamentais na Constituição Federal de 1988. 5. ed. Porto Alegre: Livraria do Advogado, 2007.

SCHWARTZ, Germano. Direito à Saúde: Efetividade em uma Perspectiva Sistêmica. Porto Alegre: Livraria do Advogado, 2001.

SILVA, Tomaz Tadeu da. Identidade e Diferença: a perspectiva dos Estudos Culturais. Petrópolis: Vozes, 2000.

TODOROV, Tzvetan. A Conquista da América: a questão do outro. Tradução Beatriz Perrone Moisés. 2. ed. São Paulo: Martins Fontes, 1999.

TOURAINE, Alain. Iguais e Diferentes: poderemos viver juntos? Tradução Carlos Aboim de Brito. Lisboa: PIAGET, 1997.

VADEMECUM Saraiva. São Paulo: Saraiva, 2011. 
VIAL, Sandra Regina Martini. Direito Fraterno na Sociedade Cosmopolita. Contribuiciones desde Coatepec, n $^{\mathbf{0}}$ 12, jan/jun, 2007.

WARAT, Luis Alberto. A rua grita Dionísio! Direitos Humanos da Alteridade, Surrealismo e Cartografia. Rio de Janeiro: Lumen Juris, 2010.

WARAT, Luis Alberto. Em nome do acordo. Buenos Aires: ALMED. Angra Impresiones, 1998.

WOLKMER, Antonio Carlos. Direito e Justiça na América Indígena: Da conquista à colonização. Porto Alegre: Livraria do Advogado, 1998. 